\title{
ポリカルボン酸系高性能 $\mathrm{AE}$ 減水剂の立体障害作用に及ぼす化学構造の影響 INFLUENCE OF CHEMICAL STRUCTURE ON STERIC STABILIZATION OF POLYCARBOXYLATE-BASED SUPERPLASTICIZER
}

\author{
名 和 豊 春*, 上松 千津子**, 大 沼 博 志*** \\ Toyoharu NAWA, Chizuko UEMATSU and Hiroshi OHNUMA
}

\begin{abstract}
The effects of chemical structures of graft copolymer on cement-dispersing performance were investigated in order to elucidate the fluidizing mechanism of polycarboxylate-based superplasticizer containing polyethylene oxide graft chains. Graft copolymer having longer graft chains showed better dispersing stability at small amount of adsorption. Moreover, the adsorption study indicated that the graft chains were stretched as increasing the adsorption density. From the experimental result of the extension for graft chains, the interparticle interaction according to the steric hindrance theory can be explained the effect of length of graft chains on cement-dispersing ability and thus we proposed the modified steric stability model.
\end{abstract}

Keywords : Polycarboxylate-based superplasticizer, Graft copolymer, Polyethylene oxide graft chain, Adsorption, Steric hindrance ポリカルボン酸系高性能 $A E$ 減水剂, グラフト共重合体, ポリエチレンオキシドグラフト鎖, 吸着, 立体障害

1.はじめに

ポリエチレンオキシド（以後PEOと記す）をグラフト鎖とした くし形共重合体を主成分とするポリカルボン酸系高性能 $\mathrm{AE}$ 減水剂 は, セメント粒子に対して高い分散安定性を示し, 低い水結合材比 でもコンクリートの流動性および流動性保持性能を著しく改善す る。このため, 高強度コンクリートや高流動コンクリートなどの高 性能コンクリートを製造する際の重要な材料となっており，より高 い分散安定性を有する分散剂を得ることが大きな関心事となり, 理 論および実験の両面から盛んに検討がなされてきている。

セメント粒子の分散安定化は, 粒子間に作用する電気的反発力と 立体障害反発力によりもたらされていると考えられている。なお, ポリカルボン酸系高性能 $\mathrm{AE}$ 減水剂を吸着させたセメント粒子の表 面電位は, 従来のナフタレン系高性能減水剂より絶対值が小さい值 を示すという知見が数多く得られている $[1]$ 。その結果, グラフト共 重合体を主成分とする高性能 $\mathrm{AE}$ 減水剂の分散安定化は, 主に立体 障害反発力に起因すると考えられている。

既往の立体障害理論によれば，吸着層中のポリマーの厚さと密度 が増すほど，立体障害反発力が増大することが予想され，長いグラ フト鎖を有する共重合体が開発されてきている。しかし，太田ら [2] はグラフト鎖長と分散安定化との関係は主鎖とグラフト鎖の幾何学 的なバランスによっても大きく異なることを指摘しており, 単純に グラフト鎖長のみに着目した立体障害反発力の変化だけでは，グラ フト共重合体のセメント粒子の分散安定化は説明しきれないと言え
る。

立体障害理論において，立体障害反発力は吸着したポリマ一間の 相互作用の総和として求められており, 発生する反発力は吸着層中 のポリマーの形態(長さ)や密度分布の影響を大きく受ける。事実, 硫酸イオン濃度によるセメントペーストの流動性の変化は，吸着層

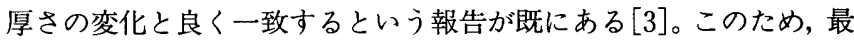
近セメント粒子表面に吸着したグラフト共重合体の形態や密度分布 に関する研究が開始されてきているが，未だ定量的なモデルを得る に至っていない。

本研究は, PEO をグラフト鎖とする 3 種類の高性能 $\mathrm{AE}$ 減水剂を 用いて，セメント粒子表面でのグラフト鎖共重合体の存在形態およ U゙吸着密度を明らかにし，分散安定化性能に及ぼす分散剤の化学構 造の影響を説明しようと試みたものである。すなわち，はじめに普 通ポルトランドセメントへの高性能 $\mathrm{AE}$ 減水剂の吸着量とペースト の流動性の関係について，単純に長さの異なるグラフト鎖の立体障 害反発力を考慮した粒子間ポテンシャルと比較しながら検討した。 次に，隣接したグラフト鎖間の相互作用を考慮した新たな吸着形態 に関するモデルに立脚して，グラフト共重合体の分子サイズと吸着 量のデータから, 吸着相中でのグラフト共重合体の形態を推定した。 さらに，推定されたグラフト鎖長に基づいて粒子間ポテンシャルを 求め, 分散安定化に及ぼすグラフト共重合体の化学構造の影響を再 度検討した。

これらの結果をもとに，化学構造が吸着層中でのグラフト鎖の吸
* 北海道大学大学院工学研究科 助教授. 工博

** 北海道大学大学院工学研究科 大学院生

*** 北海道大学大学院工学研究科 教授. 工博
Assoc. Prof., Graduate School of Engineering, Hokkaido University, Dr. Eng. Graduate Student, Graduate School of Engineering, Hokkaido University Prof., Graduate School of Engineering, Hokkaido University, Dr. Eng. 
着形態に及ぼす影響を考慮した新たな立体障害理論を提案した。

\section{2. 既往の立体障害理論に基づくグラフト鎖長の影響}

ポリカルボン酸系高性能 $\mathrm{AE}$ 減水剂の分散安定化作用は, 分散剂 分子内に有するグラフト鎖による立体障害反発力に起因し，粒子の 接近とともに粒子表面に吸着したグラフト鎖が重なり合う時の混合 効果により生じると考えられている。

粒子半径が $a$ である 2 つのセメント粒子の間に生じる，混合効果 による立体障害反発自由エネルギー $V s$ およびVan der Waals引 カポテンシャルエネルギー $V a$ は，次式で与えられる[4]。

$$
\begin{aligned}
& V s=\frac{(2 \pi)^{5 / 2}}{27}\left\langle r^{2}\right\rangle^{3 / 2} v^{2}\left(\alpha^{2}-1\right) \alpha \phi k T \\
& V a=-\frac{A}{6}\left\{\frac{2}{S^{2}-4}+\frac{2}{S^{2}}+\ln \left(\frac{S^{2}-4}{S^{2}}\right)\right\}
\end{aligned}
$$

ここに, $\left\langle r^{2}\right\rangle^{1 / 2}$ : グラフト鎖平均末端間距離, $\alpha$ : グラフト鎖の膨 張係数, $v$ : 単位面積当たりのグラフト鎖吸着数, $\phi:$ 吸着したグラ フト鎖密度分布に関するパラメーター, $k$ : Boltzmann 定数, $T:$ 絶 对温度, $A$ : Hamaker 定数, $S=(H / a)+2, a:$ 粒子半径, $H:$ 粒 子表面間距離

セメント粒子の凝集・分散は, $V s$ と $V a$ の和である粒子間全ポテ ンシャルエネルギー $V t$ によって決定され，さらに立体障害反発力 による粒子の分散安定性は, 全ポテンシャルエネルギー曲線の極小 值 $V_{\min }$ に支配され， $V_{\min }$ がー $5 k T$ 以上で分散が安定するといわれ ている。

図 1 に，セメントの粒子半径を $1 \mu \mathrm{m}$, グラフト鎖のセメント粒子 表面における吸着数 $v$ を 0.15 個 $/ \mathrm{nm}^{2}$ としたときの $V t$ 曲線を示す。 Hamaker 定数 $A$ は, 服部ら [5]がスランプロスの実験データから 求めた $1.7 \times 10^{-21} \mathrm{~J}$ とした。吸着高分子セグメント密度分布の粒子間 距離に関するパラメータ $\phi$ は, Napper[4]が求めた Tail の場合の 値を用いた。また，グラフト鎖の膨張係数 $\alpha$ の值は，著者らが既報 [6]で求めた1.05を用いた。

図 1 より，同じグラフト鎖吸着密度では，グラフト鎖の重合度が 大きくなり鎖長が長くなるほど，極小值 $V_{\min }$ の值は正の方に增大 し, $-5 k T$ 以上の分散安定化条件を満足するため, セメント粒子が 安定して分散することが予測される。

\section{3 . 分散安定化に及ぼすグラフト鎖長の影響に関する実験}

化学構造の判明しているグラフト共重合体を用いたセメントペー ストの流動性と吸着量の関係を明らかにし，両者の関係に及ぼす分 散剂の化学構造の影響を, 前章で述べた立体障害理論から求まる粒 子間ポテンシャルと比較しながら検討した。

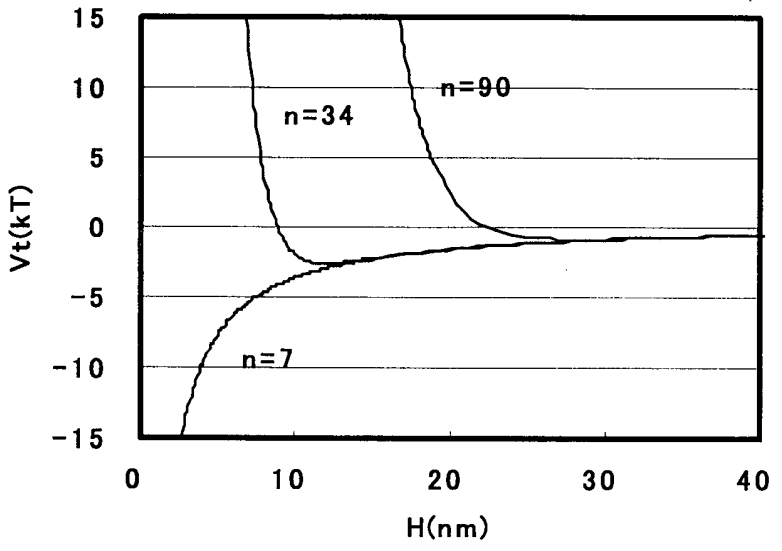

図 1 粒子間ポテンシャルエネルギー曲線

\section{1 使用材料}

セメントは普通ポルトランドセメントを用いた。セメントの化学 組成およびブレーン比表面積を表 1 に示す。

分散剂として用いたグラフト共重合体は, 無水マレイン酸グラフ ト鎤共重合体であり，グラフト鎖の PEO 重合度が $n=7,34,90$ の ものを用いた。無水マレイン酸グラフト共重合体の化学構造を図 2 に, 質量平均分子量, グラフト鎖の分子量および 1 分子中の平均グ ラフト鎖数を表 2 に示す。

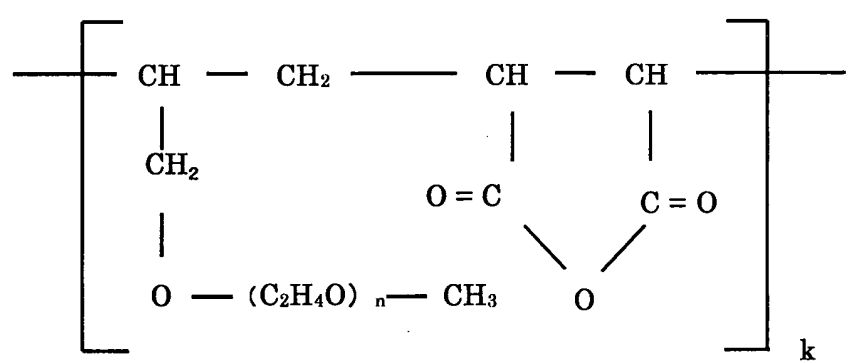

図２＼cjkstart分散剂の化学構造

\begin{tabular}{|c|c|c|c|c|}
\hline 䓽号 & $\begin{array}{c}\text { グラフトト鎖のPEO } \\
\text { 重合度(n) }\end{array}$ & \begin{tabular}{|l|} 
共重合体の賢 \\
曾平均分子量 \\
\end{tabular} & $\begin{array}{l}\text { グラフト鎖 } \\
\text { の分子量 }\end{array}$ & $\begin{array}{c}\text { 1分子中の平均 } \\
\text { グラフト鎖数 (個) } \\
\end{array}$ \\
\hline$n=7$ & 7 & 28100 & 353.4 & 58.72 \\
\hline$n=34$ & 34 & 21200 & 1542.9 & 12.71 \\
\hline$n=90$ & 90 & 44800 & 4009.8 & 10.83 \\
\hline
\end{tabular}

表 2 各分散剂の分子量と 1 分子中のグラフト鎖数

\section{2 実験方法}

(1) セメントペーストの作製

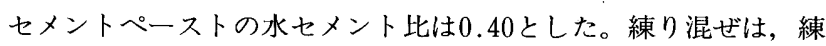
ク上がり温度が $20 \pm 2{ }^{\circ} \mathrm{C}$ となるように温度を調節した材料を一括投

\begin{tabular}{|c|c|c|c|c|c|c|c|c|}
\hline \multicolumn{8}{|c|}{ 化学組成(\%) } & \multirow{2}{*}{$\begin{array}{l}\text { ブレーン比表 } \\
\text { 面積 }\left(\mathrm{cm}^{2} / \mathrm{g}\right)\end{array}$} \\
\hline $\mathrm{MgO}$ & $\mathrm{SO}_{3}$ & $\mathrm{SiO}_{2}$ & $\mathrm{Al}_{2} \mathrm{O}_{3}$ & $\mathrm{Fe}_{2} \mathrm{O}_{3}$ & $\mathrm{GaO}$ & ig,loss & $\mathrm{Na}_{2} \mathrm{Oeq}$ & \\
\hline 2.43 & 2.03 & 20.83 & 4.75 & 2.7 & 63.15 & 1.86 & 0.6 & 3340 \\
\hline
\end{tabular}

表 1 セメントの化学組成およびブレーン比表面積 
入した後に，ハンドミキサーを用いて 5 分間練り混ぜ作製した。ま た，分散剤の添加量はセメント質量に対する固形分の質量百分率で 示した。

（2）流動性の測定

セメントペーストの流動性は, JASS15M-103に準じ, $\phi 50 \times 51 \mathrm{~mm}$ のフローコーンを用いたフロー值により評価した。

\section{(3) 吸着量の測定}

練混ぜ直後のペーストから，遠心分離 $(6,000 \mathrm{rpm} ， 3$ 分間) によ り液相を抽出した。抽出した液相をメンブランフィルター $(0.5 \mu \mathrm{m})$ を用いて， ろ過した後に，液相中の炭素量を全有機炭素測定装置 （TOC）を用いて测定した。各セメントに対する吸着量は，吸着の前 後での全有機炭素量の差から求めた。

単位面積当りの吸着量と, グラフト共重合体の分子量から, 次式 により，グラフト共重合体 1 分子当りの吸着面積が算出される。

$$
A=\frac{M w}{N a \cdot B}
$$

ここに, $A$ : 共重合体 1 分子当りの吸着面積 $\left(\mathrm{cm}^{2} /\right.$ 個 $), M w: ク ゙$ ラフト共重合体の質量平均分子量 $(\mathrm{g} / \mathrm{mole}), N a$ : アボガドロ数 (個/mole), $B$ : グラフト共重合体のセメント単位面積当りの吸着 量 $\left(\mathrm{g} / \mathrm{cm}^{2}\right)$

なお，グラフト共重合体のような微小な高分子の吸着を論じる場 合には，七メント粒子表面の微細構造も測定可能な BET 法による 比表面積を用いるのが適切と考えられる。太田ら[7]は, 各種粉体の ブレーン比表面積と BET 比表面積を比較し, 両者の間には, (4)式で 示される高い相関関係があることを示した。本研究でも，(4)式を用 いてセメントのブレーン比表面積から BET 比表面積を求め, 単位 表面積当りの吸着量を算出した。

$$
S_{B E T}=2.213 \cdot S_{\text {Blaine }}+426.8
$$

ここに, $S_{B E T}$ : BET 比表面積 $\left(\mathrm{cm}^{2} / \mathrm{g}\right), S_{\text {Blaine }}$ : ブレーン比表面 積 $\left(\mathrm{cm}^{2} / \mathrm{g}\right)$

\section{3 実験結果および考察 \\ (1) 流動性}

図 3 に，分散剤の添加量とペーストフロー值の関係を示す。いず れの分散剤を用いた場合においても，添加量が増加するとともにフ ロ一值は大きくなった。グラフト鎖の PEO 重合度 $n=7,34$ を用い たペーストはほぼ同様のフロー值を示し, 一方, $n=90$ を用いたぺー ストでは，同一添加量で30 $50 \mathrm{~mm}$ ほど低いフロー值を示した。

\section{（2）吸着性状}

図 4 に吸着等温線, すなわち液相中の分散剂濃度とセメント表面 に吸着した分散棛の量の関係を示す。これより，グラフト鎖の PEO 重合度が $n=7$ のグラフト共重合体では Giles の分類 [8]による $\mathrm{H}$ 型の吸着等温線を示し, 他方, $n=34,90$ のグラフト共重合体は L 型 の吸着等温線を示した。 $\mathrm{H}$ 型は, 吸着分子と吸着担体との間に親和 力が強い場合の吸着等温線である。他方, L 型は, Langmuir 型吸着 等温線であり, 吸着分子同志および吸着担体との相互作用力は $\mathrm{H}$ 型 ほど強くない場合の吸着等温線である。したがって，グラフト鎖の $\mathrm{PEO}$ 重合度が $n=7$ の無水マレイン酸グラフト共重合体の吸着は, セメント粒子との親和力が非常に強いと考えられる。一方, グラフ

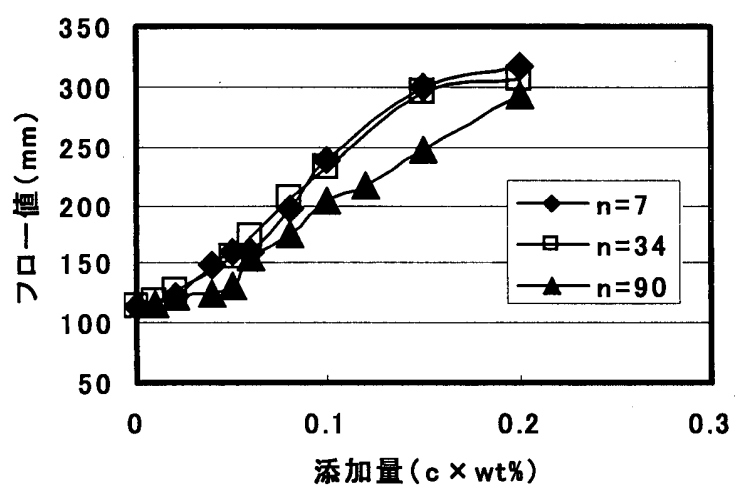

図 3 セメントペーストフロー值

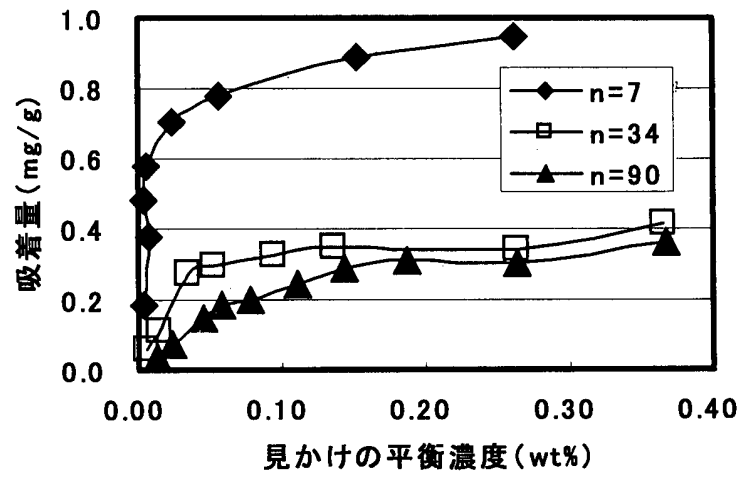

図 4 吸着等温線

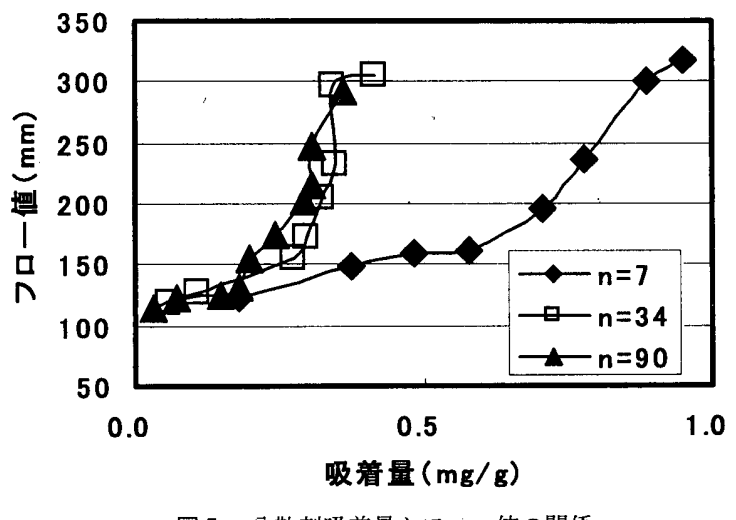

図 5 分散剂吸着量とフロー値の関係

ト鎖の PEO 重合度が $n=34,90$ のグラフト共重合体の場合は, セメ ント粒子と吸着したグラフト共重合体間に強い相互作用は生じてい ないものと推論される。

\section{（3）吸着性状と流動性の関係}

図 5 に，セメント粒子への分散剤吸着量とフロー值の関係につい て示す。図より，各分散剂毎に見ると，分散剤吸着量が増加すると 流動性も向上しているが，分散剤の種類が異なると吸着量とフロー 值の関係は異なり，グラフト鎖の PEO 重合度によってセメント粒 子の分散安定化効果が異なることが認められた。

なお，グラフト鎖長が長いとグラフト鎖/主鎖比が異なるため, 吸 着量はセメント粒子表面に吸着しているグラフト鎖の吸着密度と 1 対 1 の関係にない。このため, 表 2 に示した各グラフト共重合体中 の平均グラフト鎖数から，グラフト鎖吸着密度を求め，フロー值と 
の関係を調べた。結果を図 6 に示す。困より，明らかにグラフト鎖 の $\mathrm{PEO}$ 重合度 $n$ の影響が認められ, 例えば $n=7$ のグラフト共重 合体がフロー值 $250 \mathrm{~mm}$ を示すためには, グラフト鎖密度が 1.3 個 $/ \mathrm{nm}^{2}$ 程度であるのに対し， $n=34,90$ 共重合体では，それぞれグラフト 鎖密度が約 0.2 個 $/ \mathrm{nm}^{2}, 0.09$ 個 $/ \mathrm{nm}^{2}$ と非常に少ないことが分かる。

(4) 既往の立体障害理論に基つく粒子間ポテンシャルとの比較

立体障害理論では，図 1 に示したように，グラフト鎖の吸着量が 同じならば，グラフト鎖が長い方が粒子が分散安定化することが予 測された。また，前節の図 6 の結果においても，同じグラフト鎖吸 着密度でのペーストのフロー值は，グラフト鎖の PEO 重合度が大 きい方が明らかに大きく，セメント粒子は分散安定化することが認 められた。ここでは，実測したグラフト鎖吸着密度の值を用いて， 2 粒子間の粒子間ポテンシャル曲線を求め，立体障害理論との適合 性を検証した。

図 7 に, 各グラフト共重合体の粒子間ポテンシャル曲線を示す。 図より明らかに, グラフト鎖の PEO 重合度 $n=7$ のグラフト共重 合体では, 吸着量が増すと $V_{\min }$ は増大し, 粒子の分散が向上すると 考えられる。しかし，同時にグラフト鎖密度を 6 個 $/ \mathrm{nm}^{2}$ と非常に多 くしても， $n=34 ， 90$ 共重合体の示寸 $V_{\min }$ の值までは増大できな いことも認められる。これより, 既往の立体障害理論では, セメン 卜粒子の分散安定化の定性的な予測は可能であるが，例之ば分散剤 の材料設計に使用できるような精密な予測はできないものと判断さ れる。

\section{4. 吸着層中でのグラフト鎖の形態に関する検討}

末端を粒子表面にくくりつけられたグラフト鎖の形態は，吸着量 が増すと, ランダムコイルからくし形に変化することが de Gennes

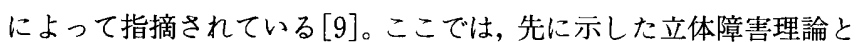
実測データの相違が，吸着層中におけるグラフト鎖の形態の変化に 起因すると考えて, 吸着層中でのグラフト鎖の形態を考察すること とした。すなわち，まずグラフト共重合体の分子サイズの推定を行 い, 次に吸着デ一タとの対応から, 吸着しているグラフト鎖の広が りの程度を算定した。

\section{1 グラフト共重合体の分子サイズの推定}

グラフト共重合体の主鎖およびグラフト鎖を構成するモノマーの 幾何学的サイズを図 2 に示した化学構造と表 2 に示した分子量の測 定データとから算出した。グラフト共重合体の主鎖部分の $\mathrm{C}-\mathrm{C}$ 結合 は，太田ら[7]の用いた0.1256nm とした。また，グラフト鎖を構成 するモノマーは，各原子間距離は共有結合長 (C-Cの結合距離を $0.154 \mathrm{~nm}, \mathrm{C}-\mathrm{O}$ の結合距離を $0.143 \mathrm{~nm}$ ）を用いて求めた。表 3 に, 各分散剂の幾何学的サイズを示す。

表 3 各分散剂の幾何学的サイズ

\begin{tabular}{|c|c|c|}
\hline 記号 & 1 分子の主鎖長さ $(\mathrm{nm})$ & グラフト鎖の長さ $(\mathrm{nm})$ \\
\hline $\mathrm{n}=7$ & 29.48 & 3.52 \\
\hline $\mathrm{n}=34$ & 6.38 & 15.4 \\
\hline $\mathrm{n}=90$ & 5.44 & 40.4 \\
\hline
\end{tabular}

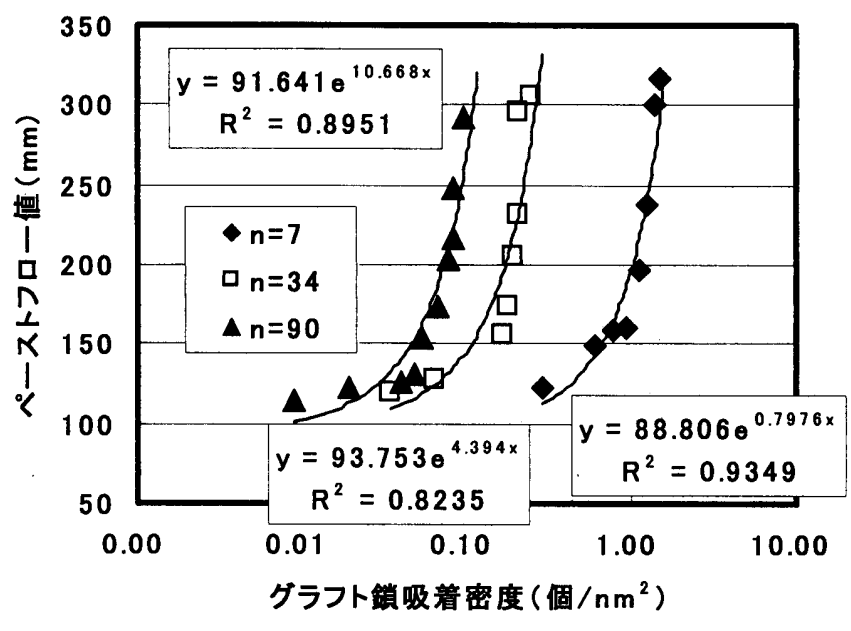

目 6 グラフト鎖吸着密度とフロー值の関係

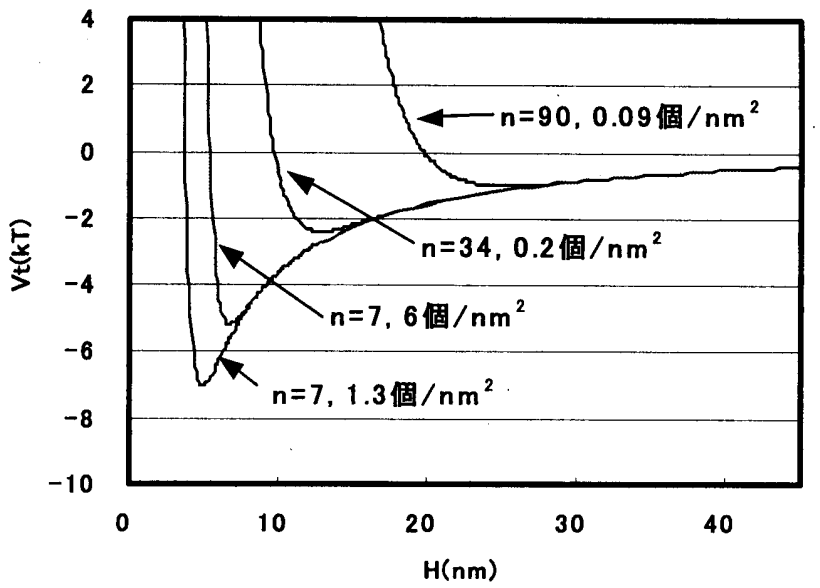

图 7 実験值から求めた吸着密度を用いて計算したポテンシャルエネルギー 曲線

\section{2 飽和時の共重合体の 1 分子あたりの吸着面積}

表 4 に，飽和吸着状態における各グラフト共重合体 1 分子あたり の吸着面積を示す。吸着面積は, グラフト共重合体の化学構造によっ て異なり，グラフト鎖の PEO 重合度が $n=7$ と小さい共重合体の 吸着面積は，他の重合度 $n=34$ 㧍よび $n=90$ の場合に比べてかなり 小さいことが認められる。なお，表 4 には，1グラフト鎖当たりの 吸着面積も示しているが, 各グラフト共重合体 1 分子当りの吸着面 積と同様な傾向が認められた。

表 4 飽和時の共重合体の吸着性状

\begin{tabular}{|c|c|c|c|}
\hline 記号 & $\begin{array}{c}\text { 吸着量 } \\
(\mathrm{mg} / \mathrm{g})\end{array}$ & $\begin{array}{c}\text { 1 分子当たりの } \\
\text { 吸着面積 }\left(\mathrm{nm}^{2}\right)\end{array}$ & $\begin{array}{c}\text { 1グラフト鎖当た } \\
\text { りの吸着面積 }\left(\mathrm{nm}^{2}\right)\end{array}$ \\
\hline $\mathrm{n}=7$ & 0.950 & 38.80 & 0.66 \\
\hline $\mathrm{n}=34$ & 0.454 & 79.42 & 6.25 \\
\hline $\mathrm{n}=90$ & 0.448 & 190.65 & 17.60 \\
\hline
\end{tabular}

\section{3 吸着したグラフト鎖の広がり}

P.M.de Gennes [9]は，粒子表面に付着した高分子（グラフト鎖） は，グラフト鎖の間隔がグラフトのランダムコイルの大きさに比べ て大きい場合には, グラフト鎖の吸着厚さ $L$ はランダムコイルと同 じ大きさとなるが(図 8 a)), 吸着量が増し被覆率が高くなると, 吸 
着したグラフト鎖が互いに接近するため，グラフト鎖はランダムコ イルよりも遠方まで伸びることを示した(図 8 b))。なお，本研究で 取り扱ったグラフト共重合体は，高分子の主鎖にグラフトされたも のであり，グラフト鎖単体を扱った de Gennes の考えをそのまま適 用できない。ここでは, de Gennesの考えを本研究で取扱っている グラフト鎖に適用できるように修正した後，前節に示した各グラフ 卜共重合体 1 分子あたりの吸着面積と各共重合体の分子サイズか ら，セメント粒子表面に吸着したときのグラフト共重合体の存在形 態について考察した。

グラフト共重合体の場合，一般にグラフト鎖間隔はグラフト鎖の 回転半径よりも短い。このため，通常は同じ分子内で隣接するグラ フト鎖は，互いの回転半径の中に入らないようにして存在しなけれ ばならないことになる。このことは，各グラフト鎖長が長くなると， 隣接するグラフト鎖は互いに重ならないような形態を取ることを要 請する。なお，共重合体の主鎖モノマー長さはグラフト鎖長さに比 べて, かなり小さいため, 主鎖の結合角, 内部回転角および排除体 積効果はグラフト鎖に比べ小さいと考えられる。以上の考察より， 主鎖は直線状にセメント粒子表面に吸着しているものと仮定した (図 9)。

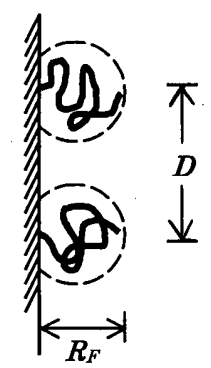

a）吸着量が少ない場合

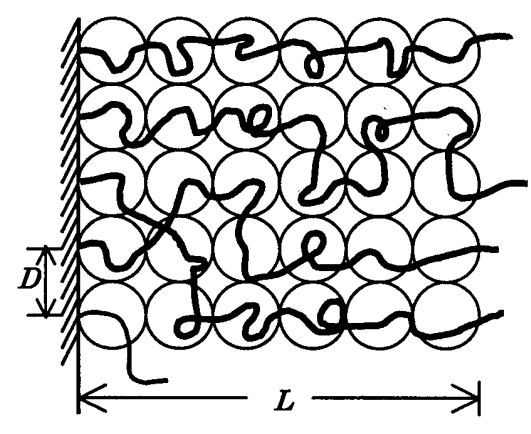

b）吸着量が多い場合

図 8 グラフト鎖の吸着形態

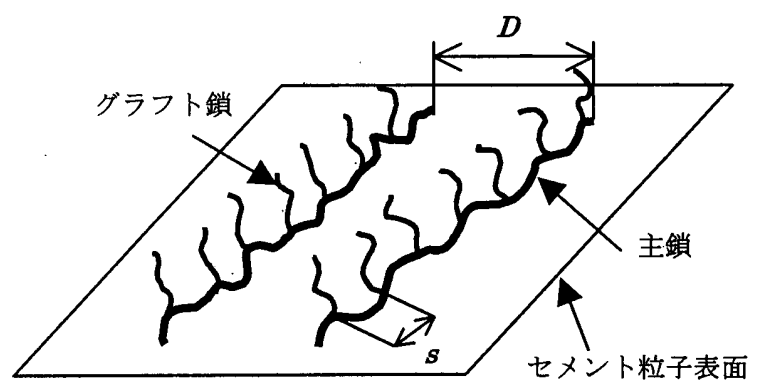

图 9 グラフト共重合体の最密充填吸着形態

一方，本研究で取り扱っているPEO をグラフト鎖とする共重合 体は，グラフト鎖は主鎖と結合しているために，グラフト鎖長が大 きくなると，主鎖軸上のグラフト鎖距離 $s$ は吸着密度に拘わらずラ ンダムコイルよりも小さくなる。したがって，de Gennesの考之に 基づくならば，本研究で対象としたグラフト共重合体中のグラフト 鎖は吸着密度に拘わらず伸長することが予想される。

しかし，この場合でも，グラフト鎖は主軸方向以外の方向は拘束 されないため，平面的に膨張しているコイルの形態をとることが可
能である。一方, 溶融ポリマーにおいて平面的に伸張するポリマー の広がりは 3 次元的な広がりとほぼ同じであると考えられており [10], 本研究では, Flory 半径 $R_{F}$ が主鎖のグラフト間距離よりも大 きくなるグラフト鎖の場合，コイルは平面的に伸張し，その大きさ はランダムコイルと同じ大きさになると仮定する。良溶媒中でのラ ンダムコイルの大きさはF Flory 半径で表される。

$$
L=R_{F}=b n^{3 / 5}
$$

ここに, $b: \mathrm{PEO}$ モノマーの有効セグメント長, $n: \mathrm{PEO}$ 重合度

なお，さらに吸着量が增し，隣接したグラフト共重合体のグラフ 卜鎖間隔がある值より小さくなると, 図 8 b)に示すようにグラフト 鎖は急激に伸長することが予想される。今，2次元的に伸長したグ ラフト鎖のセメント表面への投射面積は $R_{F}{ }^{2}$ となり, さらに伸張す る直前のグラフト鎖は, セメント粒子表面に最密充填になるように 配置されると考えられる。

各グラフト共重合体間の距離を $D$, グラフト鎖間の距離を $s$ とす ると，上記の仮定条件は，吸着したグラフト鎖が伸張する限界の吸 着量, 言い換えると限界吸着密度 $\sigma\left(=b^{2} /(D \cdot s)\right)$ が, 以下の式を 満足することを要請する。

$$
\sigma<b^{2} / R_{F}^{2}=n^{-6 / 5}
$$

なお，PEO 重合度が増しグラフト鎖が長くなる程，コイルも大き くなり，グラフト鎖がお互いに接近するため，グラフト鎖は伸長し 易くなる。de Gennesによれば，伸長したグラフト鎖は，吸着した 壁に垂直な blob (大きさ $D$ ) の直線的な糸に置換でき，その厚さ $L$ は次式のように表され， $n$ に比例する。

$$
L=n b \sigma^{1 / 3}
$$

(7)式より，吸着厚さ $L$ はPEO 重合度 $n$ に比例し，ランダムコイ ルに比べ伸張することがわかる。表 5 に飽和吸着量における各グラ フト共重合体の吸着密度 $\sigma$ 実験值を用いて(7)式から求めた吸着 層厚さ $L$ とグラフト鎖の Flory 半径 $R_{F}$ を示す。これより，吸着厚 さ $L$ はランダムコイル長 $R_{F} よ り も$ 伸張していることが判明した。 なお，その伸長の程度はグラフト鎖重合度 $n$ によって異なり，吸着 厚さ $L(\mathrm{~nm})$ は，次式のように表された。

$$
\begin{array}{ll}
L=0.44 n^{0.79} & (n=7) \\
L=0.44 n^{0.67} & (n=34,90)
\end{array}
$$

表 5 飽和時の各グラフト鎖共重合体のグラフト鎖の推定長さ

\begin{tabular}{|c|c|c|c|}
\hline 記号 & $\begin{array}{c}\text { 吸着密度 } \\
\sigma\end{array}$ & $\begin{array}{c}\text { グラフト銷の } \\
\text { Flory 半径 } \\
R_{F}(\mathrm{~nm})\end{array}$ & $\begin{array}{c}\text { 推定グラフト } \\
\text { 鎖吸着厚さ } \\
L(\mathrm{~nm})\end{array}$ \\
\hline $\mathrm{n}=7$ & 0.29 & 1.41 & 2.05 \\
\hline $\mathrm{n}=34$ & 0.03 & 3.65 & 4.70 \\
\hline $\mathrm{n}=90$ & 0.01 & 6.55 & 8.81 \\
\hline
\end{tabular}

\section{4 既往の研究によるグラフト鎖伸張モデルの検証}

前述のグラフト鎖の伸張モデルが, 実際の吸着層中のグラフト鎖 長さを予測しているか判断するためには，吸着層厚さの実测值が(5) 
式あるいは(7)式に従うことを確認する必要がある。

坂井ら [11］ [12]は，アルミナを吸着担体として，本研究で用い たのと同じ，無水マレイン酸を主鎖に，PEOをグラフト鎖とするグ ラフト共重合体の吸着層厚さ $L$ を, 流体力学的に測定している。図 10は, 坂井らの測定した吸着層厚さから，主鎖の吸着厚みとして太 田ら [ 7 ] 結果に基づき0.83nm を差し引いた值とグラフト鎖重合 度の関係を示したものである。

図より明らかに，グラフト鎖の PEO 重合度で伸張挙動が異なり， PEO 重合度が $n=7$ のように吸着担体との親和力が大きいグラフ ト共重合体では, グラフト鎖長は PEO 重合度 $n$ にほぼ比例する。一 方, PEO 重合度が $n=34 や ~ n=90$ と親和力が余り大きくないグラフ 卜共重合体では, グラフト鎖吸着厚さは $n$ の0.77乗に比例した。こ れより, 吸着したグラフト鎖の吸着厚さ $L$ は吸着密度 $\sigma$ の影響を受 け, PEO 重合度が $n=11$ 以下のグラフト共重合体では, グラフト鎖 が伸長しているのが確認される。一方, PEO 重合度が $n=34$ 以上の グラフト鎖共重合体では，吸着したグラフト鎖密度があまり高まら ないため, グラフト鎖はランダムコイルに近い形態で吸着している ものと考えられる。

なお, セメントへの吸着量を用いて(7)式から予測されたグラフト 鎖の吸着厚さ $L$ と $\mathrm{PEO} の$ 重合度 $n$ との関係を表すべき乗の係数 が異なるのが認められるが, これは, 坂井らの用いた粉体が $\mathrm{Al}_{2} \mathrm{O}_{3}$ で あり, セメントよりグラフト共重合体との親和力が強く, 吸着量が 多いため若干伸長したものと考えられる。

\section{5．グラフト鎖の伸張を考慮した立体障害機構}

グラフト共重合体を主成分としたポリカルボン酸系高性能 $\mathrm{AE}$ 減 水剂によるコンクリートの流動化は, 吸着したグラフト鎖層の立体 障害作用によるセメント粒子の分散安定化によるという立場に立脚 し，ここでは，グラフト鎖の吸着密度による伸長を考虑しな立体障 害安定化メカニズムについて考察する。なお，メカニズムの考察に あたり, 本研究では, 既往の立体障害反発ポテンシャルエネルギー の算定式を用い, さらに本研究の成果に基づいて以下に示寸作業仮 説を設定した。

1）グラフト共重合体の立体障害作用は, 主にグラフト鎖の混合効 果によるものであり，吸着量で変化するグラフト鎖長の影響を受 け，その時の立体障害反発ポテンシャルは(1)式によって評価され る。

2 ）吸着した高分子のグラフト鎖の吸着厚さは, グラフト鎖の吸着 密度によって変化し，(5)式および(7)式により算出される。

3 ）なお, 主鎖の吸着厚さ $L^{\prime}$ も立体障害効果に影響を与え, その効 果は主鎖の吸着厚み分だけ，見かけ上グラフト鎖長が増大したと して評価される。

図 7 に示したグ.ラフト鎖吸着密度とフロー值の関係において，フ ロー值が $150 \mathrm{~mm}$ および $250 \mathrm{~mm}$ の時の吸着量を求め, 次に得られた 吸着量から各グラフト共重合体の吸着相中のグラフト鎖長を推定し て，2つのセメント粒子間の全相互作用エネルギーを求め，グラフ ト鎖の PEO 重合度の影響を検討した。結果を図11に示す。

図中に示した伸長を考慮しない $n=7$ の $V_{\min }$ の值は $n=34 や$ $n=90$ と比べてかなり異なったが, 伸長モデルを用いると，それぞれ

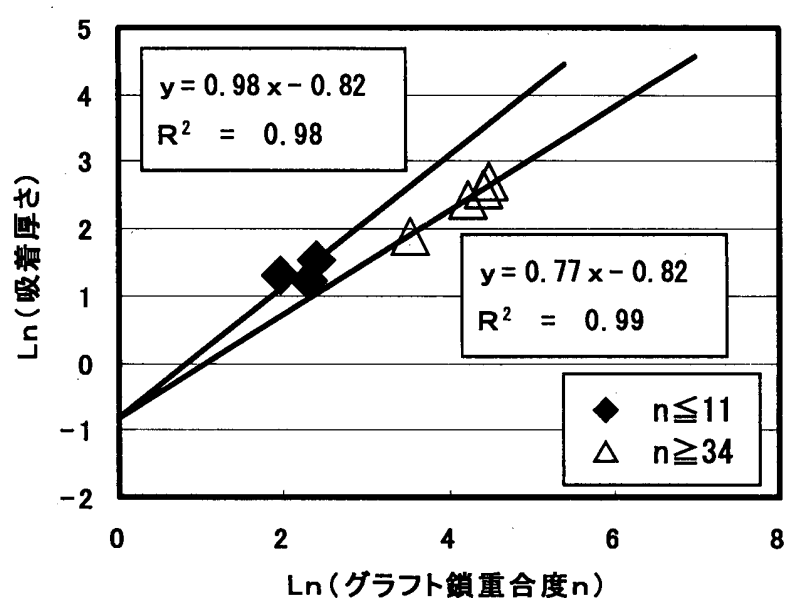

図10 吸着層厚さとグラフトさ重合度の関係
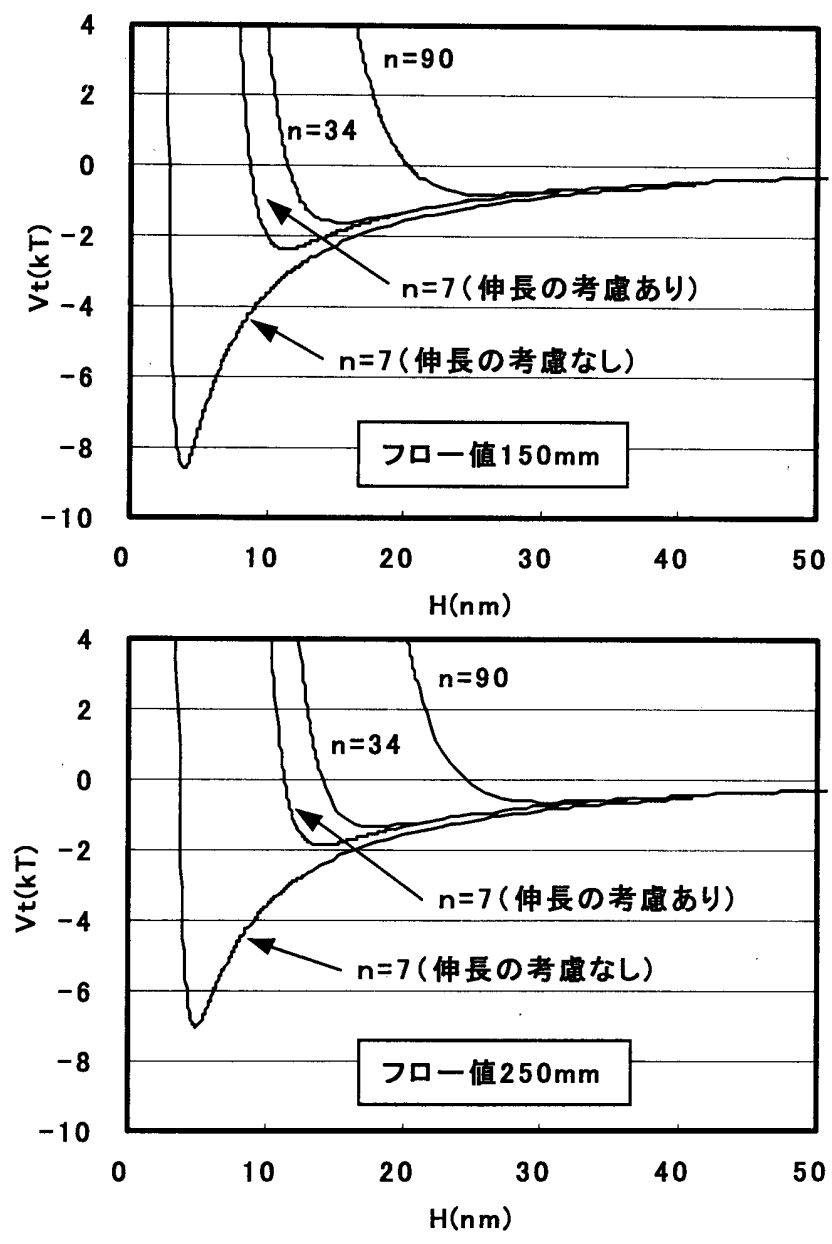

図11実験値から推定したグラフト鎖長を用いて計算した粒子間ポテンシャ ルエネルギー曲線

の $V_{\min }$ の值の差が小さくなることが示された。これより明らかに， 本研究で提案した伸長モデルを用いると，グラフト鎖長がペースト の流動性に及ぼす影響をグラフト鎖による立体障害反発力から定量 的に説明できるものと判断された。

なお，この伸長モデルに基づけば，グラフト鎖のランダムコイル 径に比べ, グラフト共重合体中でのグラフト鎖間隔が開き過ぎると, 
グラフト鎖が伸張しなくなり，セメント分散性が低下寸ると推論さ れる。また逆に，グラフト鎖間隔が小さく，グラフト鎖の方が主鎖 よりも体積比率が大きい場合には，図 4 に示した $n=34 や ~ n=90$ の グラフト共重合体のように，セメント粒子への吸着量，言い換える とグラフト鎖の吸着密度が低下し, セメント分散性が低下すると考 えられる。これより，グラフト鎖と主鎖の適切な長さのバランスが 存在することが予想される。このことは, セメントペーストの流動 性をもっとも改善させるグラフト鎖長さが存在し，それ以上のグラ フト鎖長では逆に流動性が低下するという, 太田ら [2]の実験結果を 良く説明する。

また，最適なグラフト鎖/主鎖比（長さ比）は，グラフト鎖長の影 響を受け，グラフト鎖が長いと最適なグラフト銷間隔 $s$ は長くなる $[2]$ 。本研究で提案した伸長モデルでも, 吸着密度が同じ ( $D$ が一定) とした時の，グラフト鎖が伸長し始める共重合体中のグラフト鎖間 隔 $s$ は次式で与えられ，グラフト鎖長さが増大するとグラフト鎖が 伸長する主鎖中のグラフト鎖間隔 $s$ も長くなることが分かる。

$$
s>\left(R_{F}^{2} / D\right)
$$

以上より，ポリエチレンオキシドをグラフト鎖とするポリカルボ ン酸系高性能 $\mathrm{AE}$ 減水剂のセメント粒子の分散安定化機構は, 基本 的にはグラフト鎖の吸着層による立体障害反発力に起因し, さらに

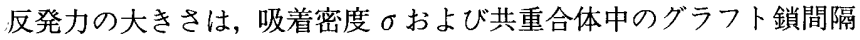
$s$ にっって決定されるグラフト鎖長の吸着厚さの影響を大きく受け るものと解釈され, 化学構造, 特に主鎖とグラフト鎖の長さ比が大 きな役割を果たすことが確かめられた。

\section{6.まとめ}

本研究では, 化学構造の異なるポリカルボン酸系高性能 $\mathrm{AE}$ 減水 剤のセメント分散機構を, 化学構造の異なる分散剤を用いて吸着し たグラフト鎖の吸着厚さに及ぼす化学構造の影響から検討したもの であり，以下にまとめて結論を述べる。

(1) $\mathrm{PEO}$ をグラフト鎖とするポリカルボン酸系高性能 $\mathrm{AE}$ 減水剂 のセメント分散安定化は, セメント粒子表面に吸着したグラフト 鎖の立体障害反発力によって説明される。

(2) ポリカルボン酸系高性能 $\mathrm{AE}$ 減水剂の吸着は, 化学構造の影響 を受け,グラフト鎖の PEO 重合度が $n=7$ と小さいと, セメント との親和力が非常に強く飽和吸着量が増すが, グラフト鎖の PEO 重合度が $n=34$ および $n=90$ のグラフト共重合体の場合は，セメ ント粒子との間にあまり強い相互作用は生じておらず，飽和吸着 量は $n=7$ に比べ低い值となった。

（3）セメント粒子表面に吸着したグラフト鎖の吸着厚さは，隣接す
る 2 つのグラフト共重合体間の平均距離 $D$, 共重合体中でのグラ フト鎖間隔 $s$ にって決定され，両者の積で表される吸着面積が グラフト鎖のランダムコイルが占有する面積よりも大きいと，コ イルはランダムコイルと同じ大きさであるが，小さいと溶液側に 向って伸長し，吸着厚さが増大することが推論された。

（4）グラフト鎖長の伸長を考慮した立体障害機構モデルは，実測し た吸着量とペーストフロー值の関係をよく説明できることが判明 し，さらに流動性に対する最適なグラフト鎖長さが存在するとい う既知の事実をよく説明した。以上より，本研究で提案したグラ フト鎖の伸長モデルを用いるとコンクリートの流動性に及ぼす分 散剂の化学構造の影響を定量的に説明できるものと判断された。

\section{参考文献}

1）例之ば，吉岡一弘，坂井悦郎，大門正機，北原文雄：セメント粒子の分散 に及ぼす高性能 $\mathrm{AE}$ 減水刘の立体障害効果の役割，コンクリート工学年 次論文報告集, Vol. 16, No. 1, pp.335 340, 1994

2) Ohta, A., et al.: Fluidizing Mechanism and Application of Polycarboxylate-based Superplasticizers Containing Polyethylene Oxide Graft Chains, Proc. Fifth CANMET/ACI International Conference on Superplasticizer and Other Chemical Admixtures in Concrete, pp.187 201, 1997

3）加藤弘義, 吉岡一弘, 牛山宏隆：高性能 $\mathrm{AE}$ 減水剤の立体障害効果に及ほ す硫酸イオンの影響, セメントコンクリート論文集, No. 51, pp.264 269, 1997

4) Napper, D.H., and Evans, R.E. : Steric Stabilization II A Generaliza tion of Fischer's Solvency Theory, Kolloid-Z.u.Z.polymere 251, 1973

5）服部健一：スランプロスのメカニズム及び対策，材料，Vol. 29，pp. $240 \sim 246,1980$

6）名和豊春，一坊寺英夫：高性能 $\mathrm{AE}$ 減水剂添加セメントペーストの流動 性に及ぼす温度の影響，コンクリート工学年次論文報告集，Vol. 20, No 2, pp.79 84, 1998

7) 太田 光, 杉山知巳, 魚本健人：ポリカルボン酸系分散剂の分散作用効果 に関する研究，セメントコンクリート論文集，No. 53，pp.122１27，1999

8) Giles, C.H., and Smith, D. : A General Treatment and Classification of Adsorption Isotherm, Journal of Colloid and Interface Science, Vol. 47, No. 3, pp.755 778, 1974

9) P.G. de Gennes : Conformation of Polymers Attached to an Interface, Macromolecules, No. 13, pp.1069 1075, 1980

10） P.G.ド・ジャン：高分子の物理学一スケーリングを中心にして, 久保亮五 監訳, 高野 宏, 中西 秀共訳, 吉岡書店, pp.47 48, 1984

11) Sakai, E., and Daimon, M. : Dispersion Mechanisms of Alite Stabilized by Superplasticizers Containing Polyethylene Oxide Graft Chains, Proc. Fifth CANMET/ACI International Conference on Superplasticizer and Other Chemical Admixtures in Concrete, pp.187 $\sim 201,1997$

12）和瀬田芳正, 坂井悦郎, 本田 進, 伊東昭則, 大門正機：溶融シリカへの 櫛形高分子の吸着と粒子間ポテンシャルの計算, Journal of the Ceramic Society of Japan, Vol. 105, No. 11, pp.1007 1011, 1997

(2000年12月18日原稿受理，2001年 3 月 12 日採用決定) 